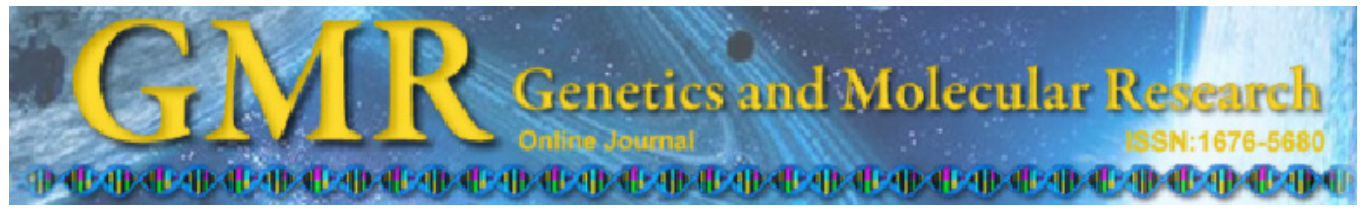

\title{
Lapachol as an epithelial tumor inhibitor agent in Drosophila melanogaster heterozygote for tumor suppressor gene wts
}

\author{
W.F. Costa ${ }^{1}$, A.B. Oliveira ${ }^{2}$ and J.C. Nepomuceno ${ }^{1,3}$ \\ ${ }^{1}$ Instituto de Genética e Bioquímica, Universidade Federal de Uberlândia, \\ Uberlândia, MG, Brasil \\ ${ }^{2}$ Departamento de Produtos Farmacêuticos, Faculdade de Farmácia, \\ Universidade Federal de Minas Gerais, Belo Horizonte, MG, Brasil \\ ${ }^{3}$ Laboratório de Citogenética e Mutagênese, \\ Centro Universitário de Patos de Minas, Patos de Minas, MG, Brasil \\ Corresponding author: J.C. Nepomuceno \\ E-mail: nepomuceno@ufu.br
}

Genet. Mol. Res. 10 (4): 3236-3245 (2011)

Received December 15, 2010

Accepted October 11, 2011

Published December 22, 2011

DOI http://dx.doi.org/10.4238/2011.December.22.1

\begin{abstract}
The search for new and effective antitumor agents with fewer cytotoxic side effects on normal tissue has increasingly become important. Lapachol, a natural organic compound isolated from the lapacho tree (Tabebuia avellandedae), is chemically identified as belonging to the naphthoquinone group and is known for its antiinflammatory, analgesic and antibiotic properties, although there are questions about its effectiveness for treating neoplasic cells. We evaluated the antitumoral effects of lapachol by testing for clones of epithelial tumors in Drosophila melanogaster. Seventy-two-hour old larvae bred from $w t s / T M 3, S b^{1}$ females and $m w h / m w h$ males, were treated with different concentrations of lapachol $(20,40$ and $60 \mu \mathrm{g} / \mathrm{mL})$. Lapachol alone did not significantly increase the number of epithelial tumors. However, lapachol did significantly reduce the number of tumors provoked by doxorubicin.
\end{abstract}

Key words: Drosophila melanogaster; Naphthoquinone; Lapachol; Doxorubicin; $w t s$ 


\section{INTRODUCTION}

Natural products extracted from plants have significantly contributed to the development of various medications used clinically in traditional medicine (Newman et al., 2003). Prospection of biological materials in plants, in areas of wide biodiversity in tropical and subtropical regions, provides chemical diversity for obtaining products for the development of new drugs (Kinghorn et al., 2003).

Natural products have been widely used for the treatment of diseases in popular medicine. Based on this tradition the use of medication produced from plants for the treatment of cancer has become common. Between 1983 and 1994, approximately 62\% of commercial drugs used to treat cancer were derived from natural sources (Ravelo et al., 2004).

Tabebuia impetiginosa, also known as "ipe", is one of the various species of plants tested for chemical substances. The active chemical compound found in this plant is naphthoquinone, also known as lapachol. Quinones are classified by the aromatic moieties present in their structure and naphthoquinone constitutes the naphtalenic ring (Silva et al., 2003).

The naphthoquinones are a class of compounds having cytotoxic properties that can be advantageous for treating cancer. Two essential mechanisms are linked to the effects of naphthoquinone, oxidative stress and nucleophilic alkylation (Bolton et al., 2000). These substances are able to accept electrons and generate reactive oxygen species (hydrogen peroxide $\left(\mathrm{H}_{2} \mathrm{O}_{2}\right)$, superoxide anion radical $\left(\mathrm{O}_{2}^{-*}\right)$ and hydroxyl radical $\left(\mathrm{HO}^{*}\right)$, whose oxidative effects could explain the cytotoxicity produced by these compounds (Boveris et al., 1978; Silva et al., 2003; de Witte et al., 2004).

Bolton et al. (2000) suggested that quinones are highly reactive molecules and can reduce the redox cycle using semi-quinine radicals, generating reactive oxygen species (ROS) that include superoxide radicals, peroxide radicals, hydrogen peroxide, and hydroxyl radicals. ROS production can cause severe oxidative cell stress, forming oxidative macromolecule cells, affecting lipids, proteins and DNA.

Lapachol (4-hydroxy-3-(3-methylbut-2-enyl)naphthalene-1,2-dione) is a natural quinone that can be isolated from many species of Bignoniaceae found in Brazil, commonly known as "ipê amarelo" (Oliveira, 2000). A number of studies have examined this natural quinine, including its anticancer, antiviral, antimicrobial, antiinflammatory, and antimalarial effects, as well as its significant effect on Trypanosoma cruzi (Carvalho et al., 1988; Grazziotin et al., 1992).

Chemotherapy agents used in treating cancer can be synthetic, semi-synthetic or natural. They are divided into five different groups, namely, alkanes, antimetabolic, natural products, hormones, and antagonists (Hardman et al., 2005).

The origin and progression of tumors in humans involves a series of genetic changes that include oncogene activation and the loss or deactivation of tumor suppressor genes (Schmandt and Mills, 1993). The importance of tumor suppressor genes has recently been recognized in new molecular techniques of studying various genes and the loss of normal alleles in different types of tumors. The byproduct of tumor suppressor genes includes cellular fixation protein, molecular transduction indicators, and transcription factors, molecules that control cell cycles and programmed cell death by apoptosis (Knudson, 1993).

The imaginal discs of Drosophila larvae have only one cellular layer that during the metamorphosis stage develops into the epidermic structures in adult flies (Edgar and Lehner, 
1996). One of the genes involved in the cellular cycle of the imaginal discs is wts (warts). Mutations in the wts genes are recessive and lethal. However, homozygotic clones that appear among heterozygotic flies in cells of imaginal discs developed epithelial tumors (previously known as warts) that are visible in the adult fly cuticles (Eeken et al., 2002). The loss or deactivation of both wts gene copies that encode a likely kinase protein depends on serine and threonine, leads to a loss of control and direction of cell proliferation in the development of the imaginal discs. Considering that the appearance of tumors is present only in the homozygosis phase due to genetic loss, wts is thought to be a tumor suppressor gene (Justice et al., 1995).

Sidorov et al. (2001) induced epithelial tumor clones in Drosophila using a lineage heterozygotic for the tumor suppressor gene wts. They studied 10 compounds of five chemical groups: polycyclic aromatic hydrocarbonates (PAH), aromatic amines, derivatives of heterocyclic aromatic N-nitrosamines, and platinum complex materials, to see how efficient they were at generating tumors.

We used Drosophila melanogaster heterozygous for the tumor suppressor gene wts to evaluate the effect of lapachol on epithelial tumors.

\section{MATERIAL AND METHODS}

\section{Chemical compounds}

Doxorubicin (DXR) (Figure 1) was manufactured by Eurofarma Laboratórios Ltda. Each bottle supplied by the manufacturer contained $50 \mathrm{mg}$ lyophilized DXR.<smiles>CC(C)=CCC1=C(O)C(=O)c2ccccc2C1=O</smiles>

Lapachol (LAP)<smiles>COc1cccc2c1C(=O)c1c(O)c3c(c(O)c1C2=O)C[C@@](O)(C(=O)CO)C[C@H]3O[C@H]1C[C@H](N)[C@@H](O)[C@@H](C)O1</smiles>

Doxorubicin (DXR)

Figure 1. Chemical structures of LAP and DXR.

Lapachol (CAS 84-79-7) was provided by Dr. A.B. Oliveira (Federal University of Minas Gerais, Belo Horizonte, Minas Gerais, Brazil). The molecular structure is shown in Figure 1. Solutions of this compound were made with $5 \%$ ethanol, immediately before use.

\section{Drosophila strains}

The following D. melanogaster strains were used: 1) wts/TM3, $S b^{1}$. This strain presents one lethal allele warts (wts) on chromosome 3, balanced by a TM3 chromosome, hav- 
ing multiple inversions, characterized by dominant stubble $(S b)$ mutation, phenotypically identified by short bristles. This strain was provided by Bloomington Drosophila Stock Center of the University of Indiana, USA, under registry No. (Bloomington/7052). 2) multiple wing hairs $(\mathrm{mwh} / \mathrm{mwh})$. Flies of the $m w h$ strain have a marker gene on chromosome 3 (3-0.3) in a distal position, having three or more hairs in each cell. The strain is kept in homozygosis since it is a viable mutation. This strain was provided by Dr. Ulrich Graf (Physiology and Animal Husbandry, Institute of Animal Science, ETH Zurich, Schwerzenbach, Switzerland).

\section{Crosses}

To obtain $w t s+/+m w h$ heterozygotic larvae, virgin female $w t s / T M 3, S b^{l}$ (Eeken et al., 2002) were mated bred to $m w h / m w h$ males. The larvae from this cross were treated with the chemical compound. However, only adult flies, without the chromosome balancer (TM3, $\left.S b^{I}\right)$ were analyzed, and they did not have truncated bristles.

\section{Experimental procedure}

Third-instar larvae $(72 \pm 4 \mathrm{~h})$ were transferred to a glass tube $(2.5 \mathrm{~cm}$ in diameter and $8.0 \mathrm{~cm}$ in length) containing $1.5 \mathrm{~g}$ instant mashed potatoes (HIKARI, Lot No. L3068DD) and $5.0 \mathrm{~mL}$ lapachol $(20,40$ or $60 \mathrm{mg} / \mathrm{mL})$ associated or not with DXR $(0.125 \mathrm{mg} / \mathrm{mL})$. The concentrations used in this experiment were based on studies of Rodrigues et al. (2005) on the lethal dose of lapachol in Aedes aegypti larvae. DXR was used $(0.125 \mathrm{mg} / \mathrm{mL})$ as a positive control and 5\% ethanol was used for a negative control. Since some compounds were photosensitive, all tubes were wrapped in aluminum foil.

The agents tested (lapachol, DXR and the combination of lapachol with DXR) were mixed with $5 \%$ ethanol before treatment. All experiments were performed at temperatures of $25^{\circ} \pm 2^{\circ} \mathrm{C}$ and $65 \%$ humidity.

\section{Scoring of warts}

After metamorphosis, the individual adults were transferred to a recipient containing $70 \%$ ethanol and males and females with genotype (wts $+/+m w h)$ and normal bristle phenotypes were identified. Tumor analysis was conducted using a stereoscopic microscope with an amplification of $25 \mathrm{X}$. Tumors were only recorded when large enough to be unequivocally classified. The tumor frequency was calculated as (number of tumors / number of wts $+/+$ $m w h$ flies) (Eeken et al., 2002).

\section{Statistical analysis}

The frequency of tumors per fly in each series was compared with the negative control to evaluate induction tumor effects. In order to assess the reduction of frequency of tumors, the frequency of tumors per fly in each treated series was compared with the positive control. Statistical comparisons were made using the non-parametric Mann-WhitneyWilcoxon U-test. 


\section{RESULTS AND DISCUSSION}

Tumors were found in the head, eyes, legs, wings, and any other part of the body of adult flies. In flies, not all precursors of different body parts are well known. In specific animal body parts, such as the eyes and legs, the cellular precursors are located in well-defined areas, during the larval stage, and are known as the cells of the imaginal disc. The development and proliferation of cells of these discs in particular are not dependent on other areas of the body. This situation is very intriguing when animals are tested at a specific age; chemical compounds that can harm the DNA cause tumors to appear (Eeken et al., 2002).

The analyses and the location of each tumor were conducted according to each region of the fly's body. These regions were distributed based on Eeken et al. (2002) findings: eyes, head, wings, body (abdomen and chest), legs, and halter (Figure 2).

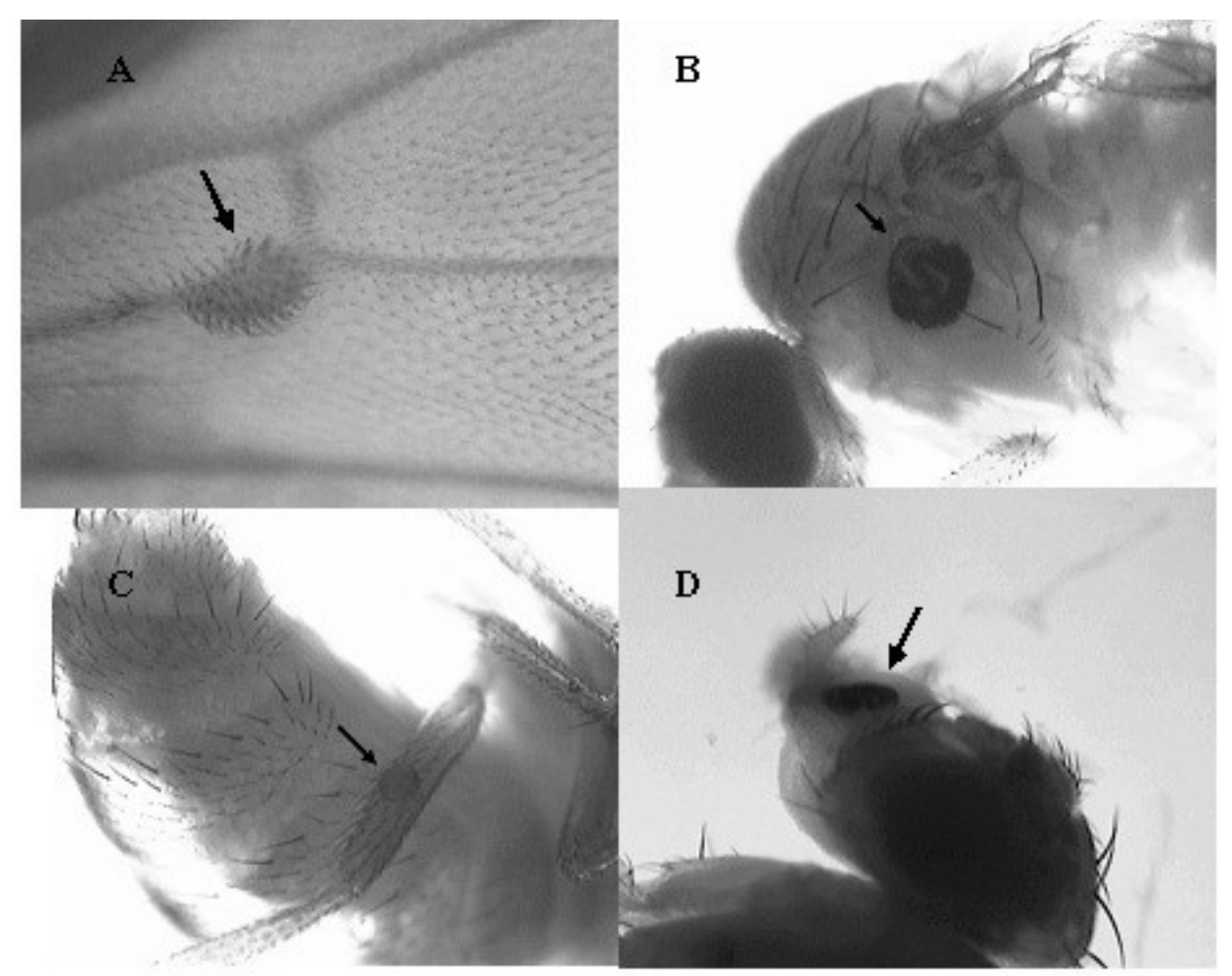

Figure 2. Tumor wts clones of different location (arrows). A. Tumor on the wing. B. Tumor on the body. C. Tumor on the leg. D. Tumor on the head.

Descendants treated with different lapachol concentration levels $(20,40$ or $60 \mu \mathrm{g} /$ $\mathrm{mL}$ ), did not show any significant changes in the frequency of tumors when compared to the negative control (5\% ethanol) (Table 1). Therefore, no significant carcinogenic effect of lapachol was found. On the other hand, DXR (used as a positive control, enhanced the frequency of tumors $(\mathrm{P}<0.05)$. 


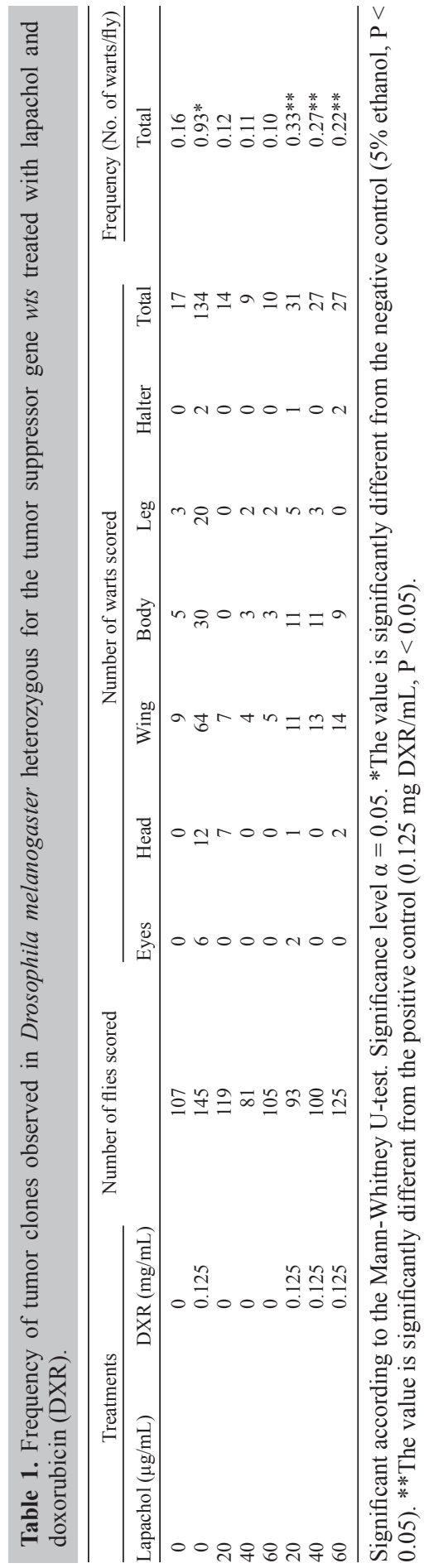


In the 145 flies analyzed and treated with DXR, 134 tumors were identified. Most of the tumors (64, equivalent to $48 \%$ of the number of tumors) were observed on the wings. The remaining tumors were distributed in other areas of the body, eyes $(4.5 \%)$, head $(9.0 \%)$, body $(22.4 \%)$, legs $(14.9 \%)$, and halters $(1.5 \%)$.

In the 107 individuals that were treated with 5\% ethanol (negative control), 17 tumors were found, indicating a spontaneous frequency. The distribution of these tumors was restricted to the wings ( 9 tumors), body (5 tumors) and legs ( 3 tumors). This rate of spontaneous frequency, with a distribution of tumors primarily on the wings and the body of the fly, was also reported by Sidorov et al. (2001). They indicated that the tumor frequencies on the wing and on the notum are the highest among all the organs because they have the largest number of cells and the longest period of cell proliferation.

Lapachol $(20,40$ or $60 \mu \mathrm{g} / \mathrm{mL})$ significantly reduced the induction of tumors by DXR $(0.125 \mathrm{mg} / \mathrm{mL})$.

The frequency of reduction of tumors was directly proportional to the concentration of lapachol. At a concentration of $20 \mu \mathrm{g} / \mathrm{mL}$, there was a reduction of $64 \%$ in the frequency of tumors induced by DXR. At a concentration of $40 \mu \mathrm{g} / \mathrm{mL}$, the reduction was $71 \%$ and at a concentration of $60 \mu \mathrm{g} / \mathrm{mL}$ a $76 \%$ reduction was noted. There was tumor reduction throughout the body of the animal, concentrated primarily on the wings and body (Figure 3 ).

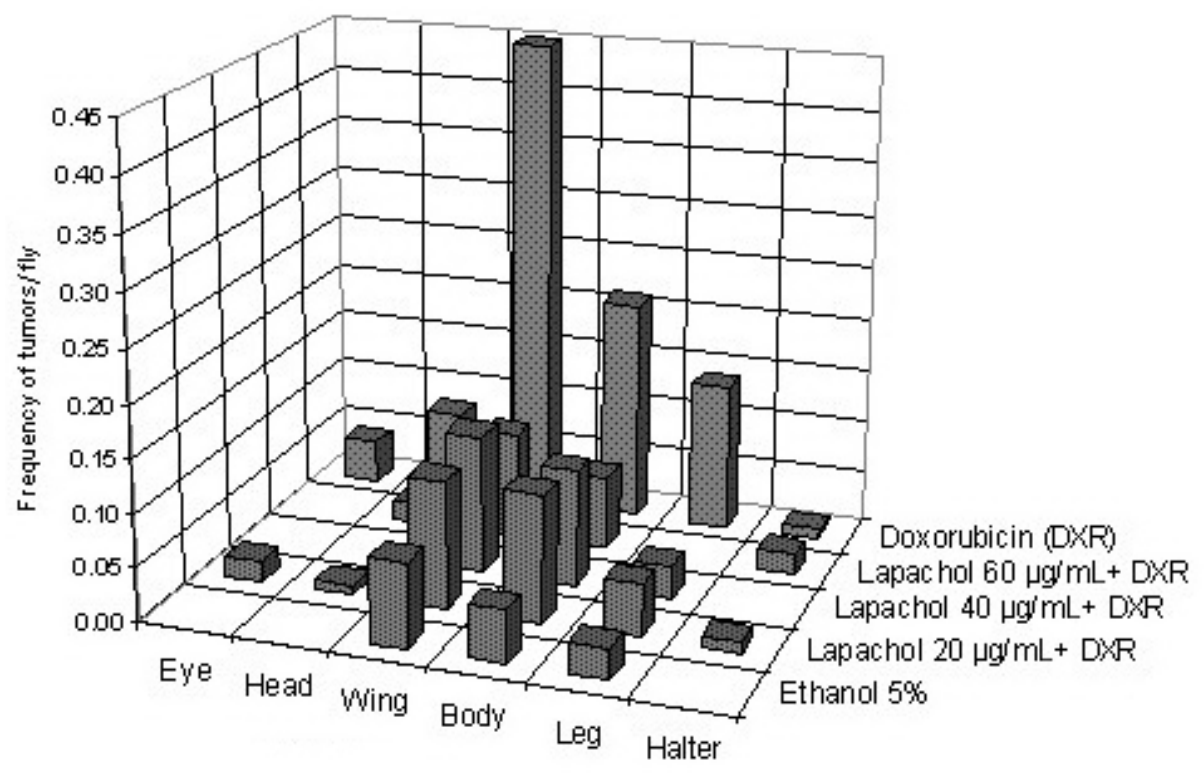

Figure 3. Frequency of the tumors after chronic treatment with different concentrations of lapachol associated with DXR $(0.125 \mathrm{mg} / \mathrm{mL})$, according to the body region of Drosophila.

The mechanisms by which lapachol reduced tumors were not analyzed. However, an understanding of the chemical structure of this compound makes it possible to link the action of lapachol to its chemical group. Quinones are organic compounds often found in plants. They are widely used as anticarcinogenic, antibacterial, antimalarial, and fungicidal agents (O’Brien, 1991). Lapachol is a quinone whose chemical structure belongs to the naphthoqui- 
none group (Falkenberg, 2003). Silva et al. (2003) reviewed the chemistry and the pharmacology of naphthoquinones. Their main interest in lapachol was its capacity to induce oxidative stress by developing intracellular ROS, such as $\mathrm{H}_{2} \mathrm{O}_{2}, \mathrm{O}_{2}^{-\bullet}$ and $\mathrm{HO}^{*}$. These species can harm some important cellular components in malignant cells. This xenobiotic interference alters the natural balance of the signals, acting during cellular division at specific points (checkpoints). Normal alterations can induce apoptosis as a possible alternative if complete oxidative stress is not eliminated.

Additional studies demonstrated that oxidative stress induced by lapachol and its effect on DNA occurs in response to the P450 cytochrome reductase enzyme biotransformation (Kumagai et al., 1997; Silva et al., 2003).

Studies conducted to analyze antitumoral properties and the action mechanism of naphthoquinone and its derivatives have shown the inhibitory effect of topoisomerase when linked to DNA. These enzymes have been successfully used in treating cancer (Wang, 1996). Esteves-Souza et al. (2007) evaluated the cytotoxicity of lapachol and its derivatives when treating Ehrlich's carcinoma and K562 leukemic cells. They reported a cytotoxic effect due to the inhibitory action of DNA-topoisomerase II. Krishnan and Bastow (2000) reported a direct beta-lapachone interaction (semi-synthetic lapachol derivative) with topoisomerase I. They concluded that the inhibitory mechanisms of topoisomerase of naphthoquinone reveals potential for developing an anticancer drug.

In 1974 the National Institute of Cancer of North America suspended all studies with lapachol, due to the need for high serum concentrations for an effective chemotherapy treatment (Suffness and Douros, 1980). The elevated amounts needed to make medication effective are extremely toxic; hence it is no longer used. None of these studies considered lapachol molecularly. Hussain et al. (2007) indicate that recent studies form the basis for the synthesis and the development of new drugs derived from lapachol that could be used in the future as a potent biomolecule. One example is the study done by Netto et al. (2010). To prepare more active and less toxic compounds, they designed new derivatives, named pterocarpanquinones, in which the pro-toxic cathecol group was changed by a naphthoquinone group (lapachol). Pterocarpanquinone showed potent antineoplasic effects against leukemic cell lines and were effective against non-small lung cancer cell lines.

Even though the National Institute of Cancer of North America suspended the use of lapachol as an antineoplasic chemotherapy drug, studies using lapachol to treat cancer continue. To analyze molecular and morphological changes caused by lapachol treatment in invasive cells, Balassiano et al. (2005) used HeLa cells exposed to different lapachol concentrations. They concluded that lapachol induces alterations in the proteins of the cell cycle and inhibits the invasion of HeLa cells, showing its potential in the fight against metastasis. Similar success in reducing metastasis was reported by Maeda et al. (2008) in mice treated with lapachol at doses between 5 and $20 \mathrm{mg} / \mathrm{kg}$.

Castellanos et al. (2009) reviewed study on lapachol and beta-lapachone and found that, despite efforts to provide scientific evidence, the lack of material, observational studies and problems associated with the lack of product quality in processing the drug to the final product minimize the efficiency of these compounds for therapeutic use. Castellanos et al. (2009) also emphasized the need for new studies, not only in vitro, but also in vivo using quality-controlled compounds.

There are also therapeutic studies using lapachol that do not involve cancer treatment. 
Many studies have demonstrated the effect of lapachol against leishmaniosis (Lima et al., 2004), Chagas disease (Carvalho et al., 1988; Grazziotin et al., 1992; Santos et al., 2001; Silva et al., 2009), and schistosomiasis (Lima et al., 2002).

Ravelo et al. (2004) suggested that lapachol has potential for preventing cancer. They also found that lapachol did not induce cancer and that it helped protect against cancer induced by DXR.

Finally, we conclude that lapachol did not show any carcinogenic activity. Although there was tumor reduction in Drosophila melanogaster epithelial cells, we suggest that further studies should be conducted to evaluate the antitumoral activity of lapachol and its chemical derivatives.

\section{ACKNOWLEDGMENTS}

We thank Dr. Robert H. Heflich (Division of Genetic and Reproductive Toxicology, Food and Drug Administration, National Center for Toxicological Research, Jefferson, AR, USA) for critical reading the manuscript. The authors also thank CAPES/CNPq/UFU for financial support and Dr. Mário Antônio Spanó for his constant support, criticism and suggestions throughout the development of the study.

\section{REFERENCES}

Balassiano IT, De Paulo SA, Henriques SN, Cabral MC, et al. (2005). Demonstration of the lapachol as a potential drug for reducing cancer metastasis. Oncol. Rep. 13: 329-333.

Bolton JL, Trush MA, Penning TM, Dryhurst G, et al. (2000). Role of quinones in toxicology. Chem. Res. Toxicol. 13: $135-160$.

Boveris A, Docampo R, Turrens JF and Stoppani AO (1978). Effect of beta-lapachone on superoxide anion and hydrogen peroxide production in Trypanosoma cruzi. Biochem. J. 175: 431-439.

Carvalho LH, Rocha EM, Raslan DS, Oliveira AB, et al. (1988). In vitro activity of natural and synthetic naphthoquinones against erythrocytic stages of Plasmodium falciparum. Braz. J. Med. Biol. Res. 21: 485-487.

Castellanos JRG, Prieto JM and Heinrich M (2009). Red Lapacho (Tabebuia impetiginosa) - a global ethnopharmacological commodity? J. Ethnopharmacol. 121: 1-13.

de Witte NV, Stoppani AO and Dubin M (2004). 2-Phenyl-beta-lapachone can affect mitochondrial function by redox cycling mediated oxidation. Arch. Biochem. Biophys. 432: 129-135.

Edgar BA and Lehner CF (1996). Developmental control of cell cycle regulators: a fly's perspective. Science 274: 16461652.

Eeken JC, Klink I, van Veen BL, Pastink A, et al. (2002). Induction of epithelial tumors in Drosophila melanogaster heterozygous for the tumor suppressor gene wts. Environ. Mol. Mutagen. 40: 277-282.

Esteves-Souza A, Figueiredo DV, Esteves A, Camara CA, et al. (2007). Cytotoxic and DNA-topoisomerase effects of lapachol amine derivatives and interactions with DNA. Braz. J. Med. Biol. Res. 40: 1399-1402.

Falkenberg MB (2003). Quinonas. In: Farmacognosia da Planta ao Medicamento (Simões CMO, Schenkel EP, Gosmann G, Mello JCP, et al., eds.). $5^{\text {a }}$ ed. UFRGS, Florianópolis. 25: 657-683.

Grazziotin JD, Schapoval EE, Chaves CG, Gleye J, et al. (1992). Phytochemical and analgesic investigation of Tabebuia chrysotricha. J. Ethnopharmacol. 36: 249-251.

Hardman JG, Limbird LE, Molinoff PB, Ruddon RW, et al. (2005). The Pharmacological Basis of Therapeutics. 9th edn. McGraw-Hill, New York.

Hussain H, Krohn K, Ahmad VU, Miana GA, et al. (2007). Lapachol: an overview. Arkivoc ii: 145-171.

Justice RW, Zilian O, Woods DF, Noll M, et al. (1995). The Drosophila tumor suppressor gene warts encodes a homolog of human myotonic dystrophy kinase and is required for the control of cell shape and proliferation. Genes Dev. 9: 534-546.

Kinghorn AD, Farnsworth NR, Soejarto DD, Cordell GA, et al. (2003). Novel strategies for the discovery of plant-derived anticancer agents. Pharm. Biol. 41: 53-67. 
Knudson AG (1993). Antioncogenes and human cancer. Proc. Natl. Acad. Sci. U. S. A. 90: 10914-10921.

Krishnan P and Bastow KF (2000). Novel mechanisms of DNA topoisomerase II inhibition by pyranonaphthoquinone derivatives-eleutherin, alpha lapachone, and beta lapachone. Biochem. Pharmacol. 60: 1367-1379.

Kumagai Y, Tsurutani Y, Shinyashiki M, Homma-Takeda S, et al. (1997). Bioactivation of lapachol responsible for DNA scission by NADPH-cytochrome P450 reductase. Environ. Toxicol. Pharmacol. 3: 245-250.

Lima NM, dos Santos AF, Porfirio Z, Goulart MO, et al. (2002). Toxicity of lapachol and isolapachol and their potassium salts against Biomphalaria glabrata, Schistosoma mansoni cercariae, Artemia salina and Tilapia nilotica. Acta Trop. 83: 43-47.

Lima NM, Correia CS, Leon LL, Machado GM, et al. (2004). Antileishmanial activity of lapachol analogues. Mem. Inst. Oswaldo Cruz 99: 757-761.

Maeda M, Murakami M, Takegami T and Ota T (2008). Promotion or suppression of experimental metastasis of B16 melanoma cells after oral administration of lapachol. Toxicol. Appl. Pharmacol. 229: 232-238.

Netto Chaquip D, da Silva AJ, Salustiano EJ, Bacelar TS, et al. (2010). New pterocarpanquinones: synthesis, antineoplasic activity on cultured human malignant cell lines and TNF-alpha modulation in human PBMC cells. Bioorg. Med. Chem. 18: 1610-1616.

Newman DJ, Cragg GM and Snader KM (2003). Natural products as sources of new drugs over the period 1981-2002. J. Nat. Prod. 66: 1022-1037.

O’Brien PJ (1991). Molecular mechanisms of quinone cytotoxicity. Chem. Biol. Interact. 80: 1-41.

Oliveira MF (2000). Contribuição ao Conhecimento Químico das Espécies Tabebuia serratifolia Nichols e Tabebuia rosa Bertol. Doctoral thesis, Curso de Pós-Graduação em Química Orgânica. Universidade Federal do Ceará, Fortaleza.

Ravelo AG, Estevez-Braun A, Chavez-Orellana H, Perez-Sacau E, et al. (2004). Recent studies on natural products as anticancer agents. Curr. Top. Med. Chem. 4: 241-265.

Rodrigues AM, de Paula JE, Roblot F, Fournet A, et al. (2005). Larvicidal activity of Cybistax antisyphilitica against Aedes aegypti larvae. Fitoterapia 76: 755-757.

Santos AF, Ferraz PA, de Abreu FC, Chiari E, et al. (2001). Molluscicidal and trypanocidal activities of lapachol derivatives. Planta Med. 67: 92-93.

Schmandt R and Mills GB (1993). Genomic components of carcinogenesis. Clin. Chem. 39: 2375-2385.

Sidorov RA, Ugnivenko EG, Khovanova EM and Belitsky GA (2001). Induction of tumor clones in D. melanogaster wts/+ heterozygotes with chemical carcinogens. Mutat. Res. 498: 181-191.

Silva AJM, Netto Chaquip D, Lima WP, Torres-Santos EC, et al. (2009). Antitumoral, antileishmanial and antimalarial activity of pentacyclic 1,4-naphthoquinone derivatives. J. Braz. Chem. Soc. 20: 176-182.

Silva MN, Ferreira VF and Souza MCBV (2003). An overview of the chemistry and pharmacology of naphthoquinone with emphasis on B-lapachone and derivatives. Quim. Nova 26: 407-416.

Suffness M and Douros J (1980). Miscellaneous Natural Products with Antitumor Activity. In: Anticancer Agents Based on Natural Product Models (JM Cassady and JD Douros, eds.). Academic Press, New York, 465-487.

Wang JC (1996). DNA topoisomerases. Annu. Rev. Biochem. 65: 635-692. 